\title{
Connecting Supreme Court Decisions, Media Coverage, and Public Opinion: The Case of Lawrence v. Texas
}

\author{
Mahalley D. Allen and Donald P. Haider-Markel
}

\begin{abstract}
Many scholars have examined the relationship between public opinion and the U.S. Supreme Court, but most researchers have often failed to take into account the fact that the press mediates this relationship. Due to the public's lack of independent knowledge about Supreme Court decisions, the media has the potential to play an influential role in the communication and interpretation of Supreme Court decisions. In this article, we examine the relationship between the Supreme Court, the media, and public opinion. First, we examine whether increased public tolerance on gay and lesbian issues has resulted in increased media coverage of gay-related cases before the Supreme Court. Second, we examine how media coverage of the Court's 2003 decision to strike down state sodomy laws in Lawrence v. Texas may have been associated with decreased public support for gay and lesbian civil rights. Our analysis suggests that increased support for gay and lesbian civil rights may have lead to increased media attention to the Lawrence case and that the tone of this coverage may have subsequently resulted in an observed decrease in support for gay and lesbian civil rights following the Court's decision. We also suggest that the release of a highly critical dissenting opinion by the Court in the case may have encouraged negative media coverage and the resulting shift in public opinion. Our research has broad implications for media coverage of Supreme Court decisions.
\end{abstract}

Many scholars have examined the relationship between public opinion and the U.S. Supreme Court (Caldeira 1987; Franklin and Kosaki 1989; Kritzer 2001; Wlezien and Goggin 1993), but researchers have often failed to take into account the fact that the press mediates this relationship (Hoekstra 2003; Slotnick and Segal 1998). Because the Supreme Court, unlike other political institutions, does not communicate directly with the public to any significant degree, the media plays a more central role in providing information to the public about the Court's decisions (Davis 1994; Hoekstra 2003; Slotnick and Segal 1998). Indeed, the dissemination of information about Supreme Court decisions "comes almost exclusively from the press" (Davis 1994, 16).

Nevertheless, most Supreme Court decisions receive little or no media coverage (Davis 1994; Hoekstra 2003; Slotnick and Segal 1996). Although issues that are not salient to the public do not receive much news media

This research was funded by a 2003 grant from the GLAAD Center for the Study of Media and Society. A previous version of this manuscript was presented at the annual meeting of the American Political Science Association, September 2004.

MAHALLEY D. ALLEN is assistant professor of political science at California State University, Chico. DONALD P. HAIDER-MARKEL is associate professor of political science at the University of Kansas.

The American Review of Politics, Vol. 27, Fall, 2006: 209-230

(c)2006 The American Review of Politics 
attention in general (Epstein and Segal 2000), this phenomenon is especially true with Supreme Court cases (Davis and Strickler 2000). Journalistic values that favor controversy and conflict tend to drive media coverage (Iyengar 1991), in part, because the public is also drawn by these issue characteristics, especially in judicial cases (Davis and Strickler 2000; Slotnick and Segal 1998). In sum, the media is likely to cover Court decisions that address issues that have already been "defined as newsworthy" by the public and, thus, are given greater weight in the media (Davis 1994; Slotnick and Segal 1998). Thus, it seems reasonable to expect that as an issue becomes more salient to the public the media will increase its coverage of this issue.

But public opinion does not simply drive media coverage - the relationship is often reciprocal - media attention and framing of an issue can also shape public opinion (Behr and Iyengar 1985; Clawson and Waltenburg 2003; Iyengar1991; Iyengar and Kinder 1987; Nelson, Clawson, and Oxley 1999; Nelson and Oxley 1999). In fact, researchers have established that when the media provides extensive coverage of an issue, it creates a context in which change in public opinion is more likely (Baumgartner and Jones 1993; Behr and Iyengar 1985; Joslyn and Haider-Markel 2000; Lewis and Rogers 1999; Shah et al. 1999). In short, although shifts in public opinion might bring about changes in media coverage of Supreme Court cases, the media may also be able to influence public opinion on policy issues related to the Court's decisions (Franklin and Kosaki 1995; Hoekstra 2003).

But how do the media play this role? Research suggests that the public has little knowledge about the Supreme Court in general or its decisions and that most people, including reporters, never read the Court's decisions (Kritzer 2001; Scherer 2003; Slotnick and Segal 1998). Therefore, much of the public's knowledge about Court decisions is dependent on interpretations provided by the media (Franklin and Kosaki 1989; Hoekstra 2003; Slotnick and Segal 1996; Wlezien and Goggin 1993). The public's lack of independent knowledge allows the media to play an especially influential role in shaping how people think about policy issues associated with the Court's decisions (Clawson and Waltenburg 2003; Franklin and Kosaki 1995; Hoekstra 2003). And indeed some research has demonstrated that the media can shape public opinion related to public policy by not only directing more or less attention to specific issues versus others, but also by assisting in the construction of an issue's image, or the dominant way in which people come to think about the issue (Baumgartner and Jones 1993; Clawson, Strine, and Waltenburg 2003; Clawson and Waltenburg 2003; Johnson and Martin 1998; Lewis and Rogers 1999; Menashe and Siegel 1998; Nelson, Clawson, and Oxley 1997; Nelson and Oxley 1999).

Baumgartner and Jones (1993) argue that an issue's policy image is largely determined by the tone of media coverage surrounding it. Tone 
incorporates the notion that certain dimensions of an issue are stressed at the expense of other dimensions in media coverage. Although media coverage of an issue often tends to present two or more sides of an issue fairly, not all newspaper articles or television programs do so, and the tone of coverage can be skewed towards one side of a policy issue. This skew might advantage one issue position over another and make that position more attractive or acceptable to the public (Baumgartner and Jones 1993; Behr and Iyengar 1985; Menashe and Siegel 1998; Nelson, Clawson, and Oxley 1997; Nelson and Oxley 1999). In terms of Supreme Court decisions, where public knowledge is so dependent on news media sources, if the tone of media coverage is biased in favor of one side of an issue, it is especially reasonable to conclude that this bias may shape public opinion on the issue (Clawson and Waltenburg 2003; Johnson and Martin 1998). Indeed, in experimental studies researchers found that how the media framed Court decisions in affirmative action and capital punishment cases affected public opinion on the issue and confidence in the Court (Clawson, Kegler, and Waltenburg 2001; Clawson and Waltenburg 2003). And Clawson, Strine, and Waltenburg confirmed that different news outlets use different issue frames to present Court decisions (Clawson, Strine, and Waltenburg 2003).

In this manuscript, we explore the relationship between the Supreme Court, media coverage, and public opinion in two ways. First, we examine the relationship between public opinion and media coverage by examining whether an increase in public support on gay and lesbian civil rights issues over the past 25 years has corresponded with increased media coverage of gay-related cases appearing before the U.S. Supreme Court. We examine this connection by exploring national and state media coverage of the four major gay rights cases decided by the U.S. Supreme Court since 1985. We expect that as public support for gay rights has increased over time, media coverage of Supreme Court decisions on gay issues also has increased.

Second, we examine how the tone of media coverage of a recent Supreme Court gay civil rights case, Lawrence v. Texas, may have been associated with decreased public support for gay rights. Lawrence was an historic decision in which the Court overruled its 1986 decision in Bowers $v$. Hardwick and struck down all state sodomy laws (Lawrence v. Texas 2003). Given the media's ability to shape public attention and potentially, opinion, through its use of tone, we expect that as the media's negative coverage of Lawrence increased, public support for gay rights decreased.

\section{Public Opinion on Gay Rights, the Supreme Court, and the Media}

Over the past 30 years public support for gay civil rights has increased steadily. This trend is clear in a variety of national surveys (Brewer 2003; 
Egan and Sherrill 2005). For example, Gallup polls reveal a steady increase in public support on a variety of gay civil rights issues. As shown in Figure 1, support for legalized homosexual relations rose from a low of 43 percent in 1977 to a high of 60 percent in May 2003, a 17 percentage-point increase. Most of this change occurred in the 1990's, when the percentage of American adults indicating approval of legal same-sex relations almost doubled (Egan and Sherrill 2005). There has also been a substantial increase in the percentage of people supporting equal employment rights for gays and lesbians, rising from 56 percent in 1977 to 88 percent in May 2003. Support for homosexual lifestyles also rose from a low of 34 percent in 1982 to 54 percent in May 2003.

Because the media is more likely to cover policy issues that are salient to the public, we anticipate that this increased public support on gay rights issues will be associated with increased media attention to gay rights cases appearing before the U.S. Supreme Court (Davis 1994). To test this idea we tracked media coverage of the four major gay rights cases decided by the U.S. Supreme Court since 1985: Bowers v. Hardwick (1986), Romer v. Evans (1996), Boy Scouts of America v. Dale (2000), and Lawrence v. Texas (2003). In Bowers v. Hardwick (1986), the Supreme Court upheld Georgia's sodomy law, ruling that the Constitution did not confer upon homosexuals a fundamental right to engage in sodomy. In the second case, Romer v. Evans

Figure 1. Public Support for Gay Civil Rights Issues, 1977 to 2003

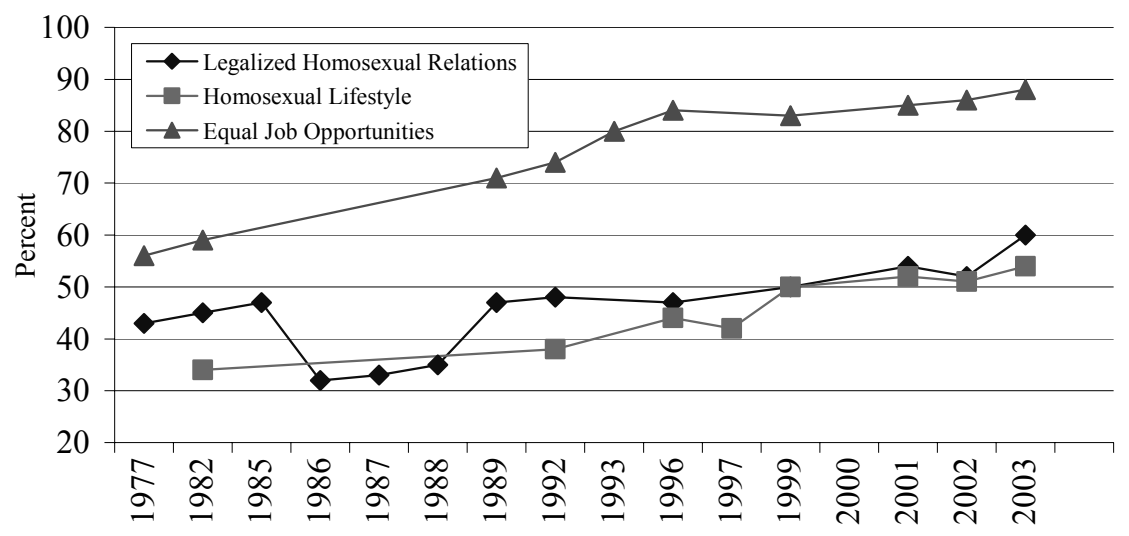

Source: Compiled by the authors from national Gallup polls of adults. Respondents were asked the following questions: "Do you think homosexual relations between consenting adults should or should not be legal?", "Do you feel that homosexuality should be considered an acceptable lifestyle or not?", and "As you may know, there has been considerable discussion in the news regarding the rights of homosexual men and women. In general, do you think homosexuals should or should not have equal rights in terms of job opportunities?" 
(1996), the Court struck down a Colorado state constitutional amendment that prohibited civil rights protections for gays and lesbians. In Boy Scouts of America v. Dale (2000), the Court upheld a Boy Scout policy excluding gays from joining the organization, ruling that a New Jersey law requiring the Boy Scouts to admit gays violated their First Amendment right of expressive association. In the last case, Lawrence v. Texas (2003), decided 17 years after Bowers, the Court overruled its decision in Bowers and effectively struck down all state sodomy laws, including laws that banned both homosexual and heterosexual sodomy, as well as those that only banned homosexual sodomy, finding that they did not further a legitimate state interest. In addition, in the majority opinion the Justices argued that the right to liberty and privacy under the Fourteenth Amendment's Due Process Clause gave people the right to engage in private sexual conduct without intervention of the government (Lawrence $v$. Texas 2003).

We begin our examination of media coverage of these four cases by tracking coverage in The New York Times, The Washington Post, and in the capital city newspaper in the state in which each case originated through keyword searches using the Lexis-Nexis and NewsLibrary newspaper archives or the newspaper's own database. ${ }^{1} \mathrm{We}$ compare national newspapers to state newspapers simply because coverage by smaller regional papers may not be as extensive and may or may not be as neutral as national papers (Clawson, Strine, and Waltenburg 2003; Hoekstra 2003). We chose state newspapers from the states where cases originated simply because these states had a vested interest in these cases and previous research has suggested that the "local angle" would ensure greater coverage, more comparable to national newspaper coverage (Hoekstra 2000, 2003). For each case, we tracked coverage from the time the Court granted certiorari in the case until one month after the decision was handed down in the case. Table 1 displays the number of articles, total word count of all articles, and average word count per article.

The data suggest that coverage of gay rights cases by the national media has tended to increase over time with the number of articles and total words devoted to the case on the increase since 1985. Although the New York Times only printed 24 articles discussing the Bowers case, it steadily increased its coverage of the other cases over time, printing 68 articles focusing on the Lawrence case. We find a similar pattern with the Washington Post's coverage. The Post only printed 26 articles about Bowers but significantly increased its coverage of Lawrence, printing 56 articles about it. And as shown in Figure 2, which tracks coverage in the New York Times of gay and lesbian issues more generally, the pattern does increase over time, with an especially large spike in coverage in 2003, as the June decision was released for Lawrence. 
Table 1. Comparison of Newspaper Coverage on Four Major Gay Rights Cases Decided by the U.S. Supreme Court, 1985 to 2003

\begin{tabular}{|c|c|c|c|}
\hline $\begin{array}{l}\text { Case } \\
\quad \text { Newspaper }\end{array}$ & $\begin{array}{l}\text { Number of } \\
\text { Articles }\end{array}$ & $\begin{array}{l}\text { Total Word Count } \\
\text { for All Articles }\end{array}$ & $\begin{array}{l}\text { Average Word } \\
\text { Count per Article }\end{array}$ \\
\hline \multicolumn{4}{|l|}{ Bowers v. Hardwick (1986) } \\
\hline New York Times & 24 & 25,101 & 1091.35 \\
\hline Washington Post & 26 & 25,852 & 1034.08 \\
\hline State: GA, Atlanta JC & 10 & 5,943 & 660.33 \\
\hline \multicolumn{4}{|l|}{ Romer v. Evans (1996) } \\
\hline New York Times & 36 & 37,949 & 1084.26 \\
\hline Washington Post & 17 & 18,251 & 1073.59 \\
\hline State: CO, Denver Post & 73 & 62,402 & 854.82 \\
\hline \multicolumn{4}{|l|}{ Boy Scouts v. Dale (2000) } \\
\hline New York Times & 49 & 51,508 & 1051.18 \\
\hline Washington Post & 31 & 27,044 & 872.39 \\
\hline State: NJ, Star-Ledger & 35 & 28,125 & 803.57 \\
\hline \multicolumn{4}{|l|}{ Lawrence v. Texas (2003) } \\
\hline New York Times & 68 & 67,399 & 991.16 \\
\hline Washington Post & 56 & 53,334 & 952.39 \\
\hline State: TX, Austin & 19 & 18,156 & 955.58 \\
\hline \multicolumn{4}{|c|}{$\begin{array}{l}\text { Source: Compiled by the authors based on keyword searches of the Lexis-Nexis newspaper archive } \\
\text { and NewsLibrary. Newspaper articles are simple counts of the number of articles dealing with each } \\
\text { Supreme Court case from the time cert was granted in the case through one month following the } \\
\text { Court's decision in each case. The articles from each paper were then used to compile the total num- } \\
\text { ber of words in all articles for each newspaper and the average number of words per story by news- } \\
\text { paper. For each case we searched The New York Times and The Washington Post, as well as the state } \\
\text { capital newspaper for the state in which each case originated. Time periods for each case: Lawrence: } \\
\text { Cert granted } 12 / 2 / 02 \text {, Oral argument } 3 / 26 / 03 \text {, Decision } 6 / 26 / 03 \text {. Bowers: Cert granted } 11 / 4 / 85 \text {, Oral } \\
\text { argument } 3 / 31 / 86 \text {, Decision } 6 / 30 / 86 \text {. Romer: Cert granted } 2 / 21 / 95 \text {, Oral argument } 10 / 10 / 95 \text {, } \\
\text { Decision } 5 / 20 / 96 \text {. Boy Scouts: Cert granted } 1 / 14 / 00 \text {, Oral argument } 4 / 26 / 00 \text {, Decision } 6 / 28 / 00 \text {. }\end{array}$} \\
\hline
\end{tabular}

Coverage of gay rights cases by state capital newspapers also has tended to increase over time on all counts. Local coverage of Romer (1996) and Dale (2000), especially, increased considerably over local coverage of Bowers (1986). Although the Austin American Statesman's coverage of Lawrence was less than local coverage of Romer or Dale in all areas except the average number of words per article, its coverage was still considerably higher than the Atlanta Journal Constitution's coverage of the Bowers sodomy decision.

A comparison of the amount of national and state media coverage of the four gay civil rights cases over time with the public opinion data about gay civil rights issues shown in Figure 1 suggests that the two are correlated. 
Figure 2. New York Times Articles
on Gay and Lesbian Issues, 1977-2005

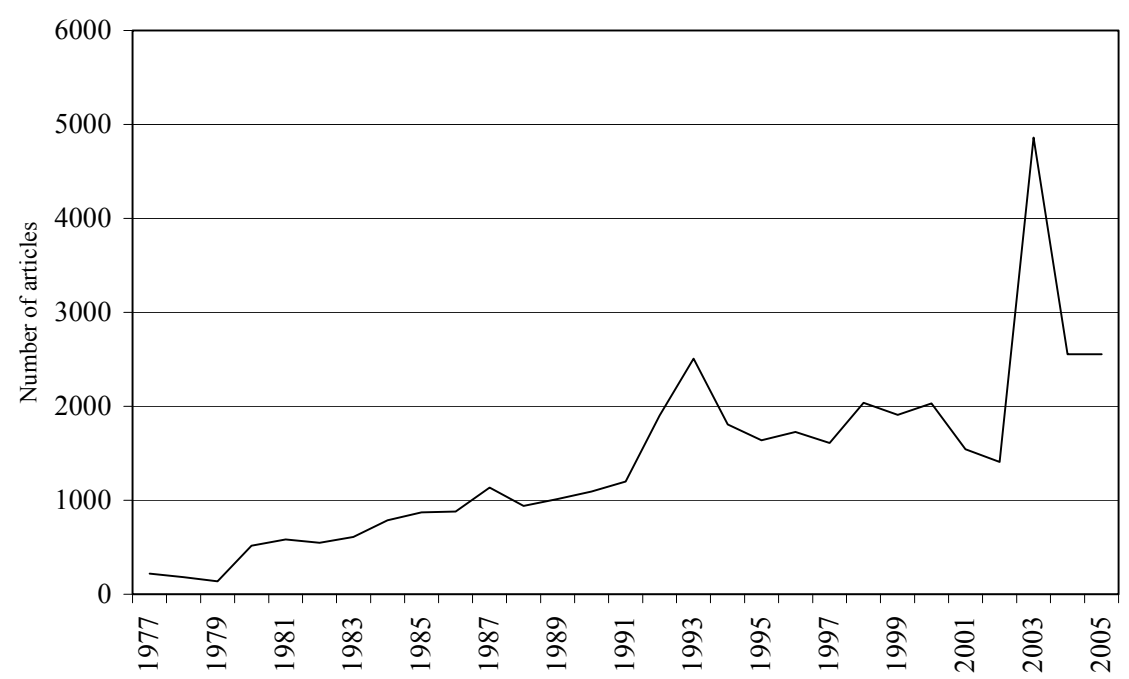

Source: Compiled by the authors based on keyword searches of the Lexis-Nexis newspaper archive for the New York Times using the terms homosexual, gay, and lesbian.

Beginning in 1986 following Bowers, the amount of media coverage of gay civil rights cases increased over time as public support for gay and lesbian issues increased, with both peaking in May 2003, just before the Lawrence decision was handed down. The peak in coverage corresponds with the peak in public support on gay rights issues. By early 2003, when public support for gay rights issues was at its highest, on the whole newspapers were providing their most extensive coverage of Supreme Court decisions on gay rights. This pattern is also confirmed in Figure 2, which tracks overall coverage of gay and lesbian issues. Indeed, a simple Pearson's R correlation between public support of legal same-sex relations and overall media coverage reveals a correlation of $.63(\mathrm{p} .>.000){ }^{2}$ Thus, the evidence indicates that increased support on gay civil rights is associated with both the increase in media coverage of Supreme Court gay rights cases and overall coverage of gay and lesbian issues. Although we cannot definitively prove the influence of public opinion on gay rights issues on media coverage of Supreme Court gay rights cases, our findings are suggestive that the media does indeed respond to changes in public opinion and adjusts its coverage of Supreme Court cases accordingly. 


\section{Media Coverage of Lawrence v. Texas and Public Opinion}

We now turn to the issue of the Court's ability to influence public opinion when its decisions are interpreted through the lens of the news media. As previous research has established, Court decisions can influence public opinion, but this influence is highly conditional on media coverage of the decision (Franklin and Kosaki 1989, 1995; Hoekstra 2000, 2003). Therefore, we ask, can the media influence public attitudes by the way in which it covers a particular Supreme Court decision? To address this question, we examined whether media coverage of the Supreme Court's recent decision in Lawrence v. Texas may have been associated with shifts in public support for gay and lesbian civil rights.

Although there had been a steady increase in public tolerance on gay and lesbian issues during the past 25 years, a series of Gallup surveys reveal a significant shift in public opinion on gay rights issues following the Supreme Court's June 2003 decision in Lawrence v. Texas, with the public becoming less supportive on a variety of gay rights issues. Table 2 shows the clear shifts in public opinion that occurred abruptly following the Lawrence decision. In May 2003, prior to the Court's decision, support for legalized homosexual relations reached a historic high of 60 percent. However, a Gallup poll conducted just 2 months later in July reveals a substantial 12 percentage-point plummet in support. This shift in opinion on support for legal homosexual relations is central to our analysis simply because Lawrence directly answered the question of whether states can ban same-sex relations.

Responses to questions on support for civil unions and homosexual lifestyles reveal similar, but slightly smaller, public opinion shifts. In May 2003, 54 percent of the public agreed that a homosexual lifestyle was acceptable. By July 2003, however, that number had dropped 8 percentage points. Similarly, in May 2003, 49 percent of the public supported civil unions for gays and lesbians. Two months later, that number had dropped by 9 percentage points to only 40 percent. This represented the lowest support for civil unions found since Gallup began asking the question in October 2000 (Newport 2003). Overall, public support on these gay rights issues decreased 8 to 12 points in just 2 months. Given that the largest drop in public support came on the survey question most directly relevant to the decision in Lawrence, and other measures of public support on gay rights showed slightly smaller decreases, we interpret the pattern to suggest that the public clearly responded most strongly to the decision based on the actual case before the Court and not broader forces in the political environment that may have helped to shape public opinion. 
Table 2. Comparison of Public Support on Gay Rights Issues Before and After the Supreme Court's June 2003 Decision in Lawrence v. Texas

\begin{tabular}{|c|c|c|c|c|c|}
\hline & May 2001 & May 2002 & May 2003 & July 2003 & May 2004 \\
\hline $\begin{array}{l}\text { Support for } \\
\text { Legalized } \\
\text { Homosexual } \\
\text { Relations }\end{array}$ & $54 \%$ & $\begin{array}{c}52 \% \\
(+2 \%)\end{array}$ & $\begin{array}{c}60 \% \\
(+8 \%)\end{array}$ & $\begin{array}{c}48 \% \\
(-12 \%)\end{array}$ & $\begin{array}{c}52 \% \\
(+4 \%)\end{array}$ \\
\hline $\begin{array}{l}\text { Support for } \\
\text { Homosexual } \\
\text { Lifestyles }\end{array}$ & $52 \%$ & $\begin{array}{c}51 \% \\
(-1 \%)\end{array}$ & $\begin{array}{c}54 \% \\
(+3 \%)\end{array}$ & $\begin{array}{c}46 \% \\
(-8 \%)\end{array}$ & $\begin{array}{c}54 \% \\
(+8 \%)\end{array}$ \\
\hline $\begin{array}{l}\text { Support for Ci } \\
\text { Unions for } \\
\text { Homosexuals }\end{array}$ & $44 \%$ & $\begin{array}{c}46 \% \\
(+2 \%)\end{array}$ & $\begin{array}{c}49 \% \\
(+3 \%)\end{array}$ & $\begin{array}{c}40 \% \\
(-9 \%)\end{array}$ & $\begin{array}{c}49 \% \\
(+9 \%)\end{array}$ \\
\hline \multicolumn{6}{|c|}{$\begin{array}{l}\text { Source: National Gallup polls of adults. Respondents were asked the following questions: "Do you } \\
\text { think homosexual relations between consenting adults should or should not be legal?" "Do you feel } \\
\text { that homosexuality should be considered an acceptable lifestyle or not?," and "Would you favor or } \\
\text { oppose a law that would allow homosexual couples to legally form civil unions, giving them some } \\
\text { of the legal rights of married couples?" Changes in percentages since previous poll are given in } \\
\text { parenthesis. }\end{array}$} \\
\hline
\end{tabular}

One explanation for this shift in opinion is that the Gallup sample was biased in some manner or that Gallup made some other error. We can eliminate this explanation by briefly examining results from other polls. For example, a CBS News/New York Times poll conducted in December 2003 found that the percentage of adults indicating "homosexual relations between consenting adults should be legal" dropped to 41 percent from the 54 percent providing the same answer in June 2003. Likewise, the General Social Survey (GSS), which has asked a question regarding whether or not homosexual relations are always wrong, almost always wrong, sometimes wrong, or not wrong at all since 1972, found that although the percentage of respondents responding sometimes not or never wrong had increased significantly since 1990, between the late 2001 and late 2003 surveys the percentage of respondents giving these answers declined about 3 percentage-points. Although this shift appears small, given the timing of the surveys (which do not reflect the early 2003 increase in support found in other polls) and the less than 1.5 percentage point margin of error for these GSS surveys, the shift is statistically significant.

One could still maintain that each of these polls simply captured some sampling bias or broader shift among citizens, such as a move to become more religious, more conservative, a move to identify more strongly with the 
Republican Party, or the 2004 campaign against same-sex marriage. To account for this potential phenomenon, a model of opinion on same-sex relations is needed that can control for respondent demographics as well as the potential impact of the Lawrence decision within a given time frame. Thus, we used the GSS data from 1990 to 2004 and develop a model of individual opinion on same-sex relations, which is distinct from opinion regarding gay civil unions or same-sex marriage (Craig et al. 2005; Egan and Sherrill 2005; Wood and Bartkowski 2004).

Our statistical model accounts for the general upward trend in support (a simple count measure for year) and the specific potential effect of the 2003 decision in Lawrence (a dichotomous variable coded one for respondents from the 2004 survey). In addition we include a variety of demographic controls that have been shown to predict opinion on gay civil rights issues, such as gender, race, income, education, partisanship, religiosity, marital status, parenthood, and age. In short, women, whites, the wealthy, highly educated, younger, liberal, Democrats, less religious, unmarried, and childless respondents should be more likely to support legal same-sex relations (Brewer 2003; Craig et al. 2005; Haider-Markel and Joslyn 2005; Stoutenborough, Haider-Markel, and Allen 2006; Wood and Bartkowski 2004). The results of an Ordered Logit analysis of support for same-sex relations are displayed in Table 3.

Consistent with a large body of research the results clearly indicate the importance of a variety of respondent demographic characteristics in predicting attitudes; on average, the elderly, men, conservatives, Republicans, the less educated, and highly religious respondents are more likely to indicate that same-sex relations are wrong (Brewer 2003; Craig et al. 2005; Egan and Sherrill 2005; Haider-Markel and Joslyn 2005; Stoutenborough, Haider-Markel, and Allen 2006; Wood and Bartkowski 2004). The time trend variable also clearly indicates the steady increase in support over time.

Most importantly, the variable for the 2004 survey, following the decision in Lawrence, is negative and significant. This suggests that even controlling for individual characteristics and the upward trend in opinion, those respondents surveyed in 2004 were more likely to indicate that samesex relations are wrong. This evidence supports our contention that the observed change in aggregate opinion is not simply a result of sampling error or bias. ${ }^{3}$

\section{The Role of the Media}

Next, we examined whether the media's coverage of the Lawrence case may have created a context for the substantial shift in public opinion on gay rights issues by examining the tone of Lawrence coverage in newspapers and 
Table 3. Comparison of Public Support on Gay Rights Issues Before and After the Supreme Court's June 2003 Decision in Lawrence v. Texas

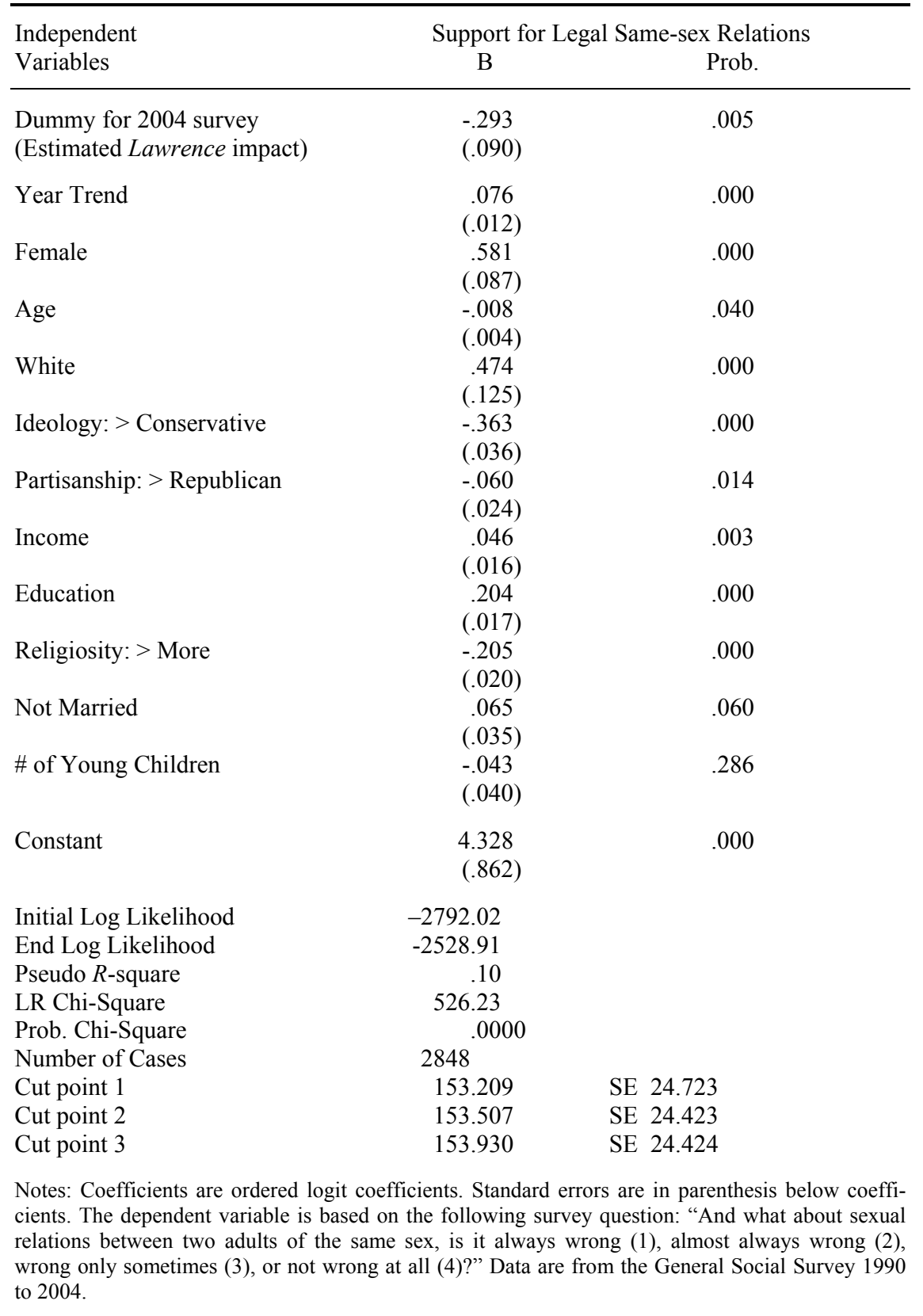


television news programs during the period that the case was before the Court. We collected data on newspaper coverage and content regarding the Texas case and sodomy laws in general from December 2002, when the Supreme Court granted certiorari in the case, through July 31, 2003. The media outlets examined were the capital city newspapers serving the four main states likely to be impacted by the Supreme Court's decision in Lawrence because they had laws banning homosexual sodomy-Kansas, Missouri, Oklahoma, and Texas - as well as the capital city newspapers in those states with heterosexual and homosexual sodomy laws-Alabama, Florida, Idaho, Louisiana, Mississippi, North Carolina, South Carolina, Utah, and Virginia - that may have been impacted by the decision. ${ }^{4}$ Because these states had laws that could be overturned by the Court in this case, their newspapers should have provided coverage that would be more comparable to national newspaper coverage (Hoekstra 2003).

We also examined national coverage of the issue in the New York Times, The Washington Post, USA Today, and the Associated Press wire service for the same time period. Coverage was explored in these outlets through a Lexis-Nexis search using the key words "sodomy" and "Lawrence v. Texas." We eliminated search hits from our database that did not pertain to the case before the Court, sodomy laws more generally, such as the history of such laws in the United States, or specifically discuss the Texas case or law.

We used a similar process to examine television news coverage of the issue from December 2002 to July 31, 2003. Here we analyzed transcripts of the daily news programs for $\mathrm{ABC}, \mathrm{CBS}, \mathrm{NBC}, \mathrm{PBS}, \mathrm{CNN}$, and FOX in a manner similar to the process outlined for newspaper articles. Again we conducted a keyword search in the Lexis-Nexis system for news programs and constructed a database to track the television news coverage.

Following Baumgartner and Jones (1993) we coded all the individual articles and news program segments according to their tone. Tone refers to the balance of coverage on a given issue. Although media coverage of an issue often tends to present both or multiple sides of an issue fairly, not all articles do so. For example, are proponents of a given law provided more space in a newspaper article than are opponents? If so, such an article can be argued to favor the position of the proponents. If relatively equal coverage is provided to both positions, then coverage can be argued to be fair or balanced, and if coverage tends to focus more on the arguments of opponents, then coverage can be argued to favor the position of opponents.

We used the arguments presented by proponents and opponents of sodomy laws in legislative debates (Haider-Markel 2000), to examine the tone of media coverage. For newspaper articles and broadcast media segments we coded on the following basis: articles and segments that generally presented arguments or ideas that favored overturning sodomy laws (over 
50 percent positive), or points of view that supporters of overturning sodomy laws would agree with, as positive, and articles or segments that generally presented arguments or ideas that opposed overturning sodomy laws (over 50 percent negative), or points of view that supporters of sodomy laws would agree with, as negative. For all tone coding those articles and segments that were not over 50 percent positive or over 50 percent negative, or where the coders were unable to judge, were coded as neutral (Baumgartner and Jones 1993; Jeon and Haider-Markel 2001). Articles and segments were coded based on the content of the full article and separately on the content of the headline (Baumgartner and Jones 1993; Jeon and Haider-Markel 2001). Likewise, news programs were coded based on the content of the full program segment pertaining to the Lawrence case, as well as each segment lead. ${ }^{5}$

Figure 3 shows the tone of state newspaper articles addressing sodomy and the Texas case from December 2002 through July 2003. ${ }^{6}$ The data make it clear that most state capital newspaper coverage of the case was neutral, but bias in coverage did tend to increase over time. In June and July 2003, as the Court released its decision and the media responded, the percentage of negative articles on the issue increased to nearly 20 percent. This pattern suggests that although state capital newspapers were generally neutral in their reporting on the case, their articles did tend to become less neutral, and more negative, in their coverage as the decision was handed down. In addition, when the bias was positive, during the spring of 2003, public support for legal same-sex relations was at its highest level recorded (see Table 2).

\section{Figure 3. Tone of State Newspaper Articles Addressing Sodomy, December 2002 to July 2003}

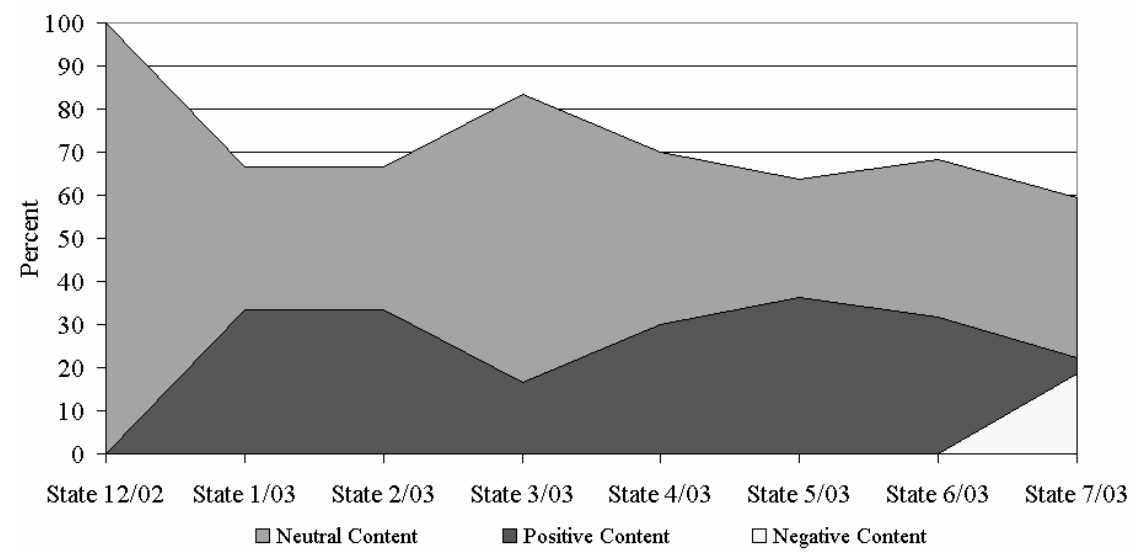

Source: Compiled by the authors. Values reflect the percentage of state capital newspaper articles using each tone. 


\section{Figure 4. Tone of National Newspaper Articles Addressing Sodomy, December 2002 to July 2003}

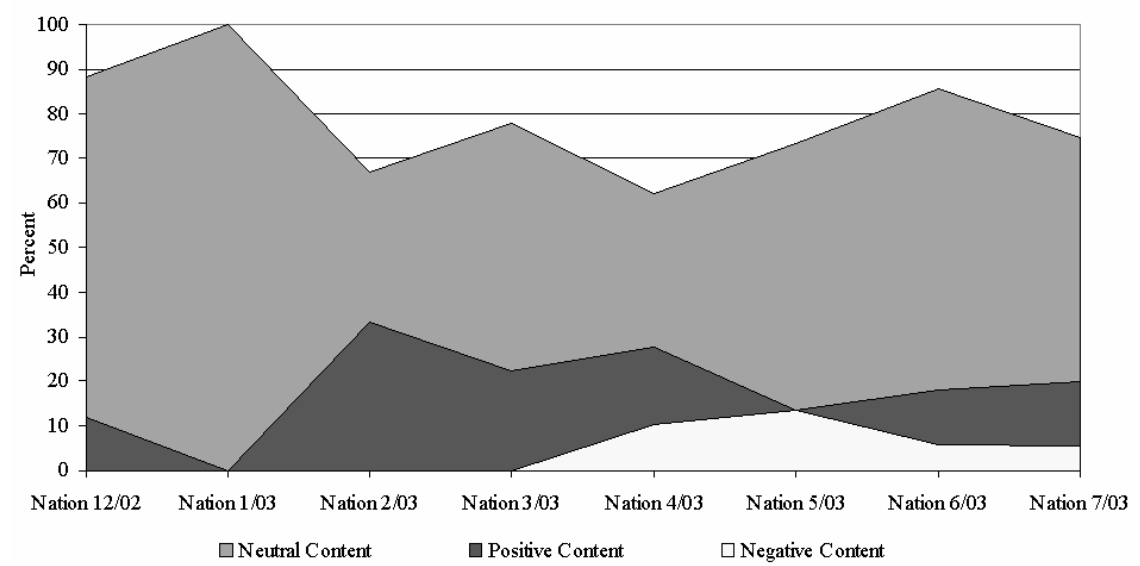

Source: Compiled by the authors. Values reflect the percentage of national newspaper articles using each tone. The compilation includes articles from the Associated Press wire service.

The tone of national newspaper articles addressing the Texas case and the sodomy issue, shown in Figure 4, is similar to the finding for the tone of state newspaper articles, but there are some differences. Although national newspapers also tended to become less neutral over time, they were more neutral overall. They also tended to have an overall greater percentage of negative articles than did state papers and a smaller percentage of positive articles. The highest percentage of negatively toned national newspaper articles appeared in April and May 2003 and concerned negative comments made by Senator Rick Santorum (R-PA) about sodomy laws and the Lawrence case. However, in June and July 2003, the percentage of negative articles in the national newspapers remained steady at almost 6 percent.

As a whole, the broadcast media were considerably more neutral in their coverage of the Lawrence case, as shown in Figure 5, than were newspapers. However, as with newspaper tone, negative coverage of the case did increase after the Supreme Court announced its decision. In June 2003, just a little over 1 percent of the broadcast media programs regarding Lawrence were negatively biased. One month later, however, that number increased to nearly 5 percent. In addition, when the bias was more positive, during the spring of 2003, public support of legal same-sex relations was at the highest level recorded (see Table 2).

These findings suggest that most media coverage of the Lawrence case was neutral. However, they also reveal a pattern whereby media coverage in both state and national newspapers and the broadcast media began neutrally 
Figure 5. Tone of Broadcast Media Segments and Programs Addressing Lawrence v. Texas and Sodomy, December 2002 to July 2003

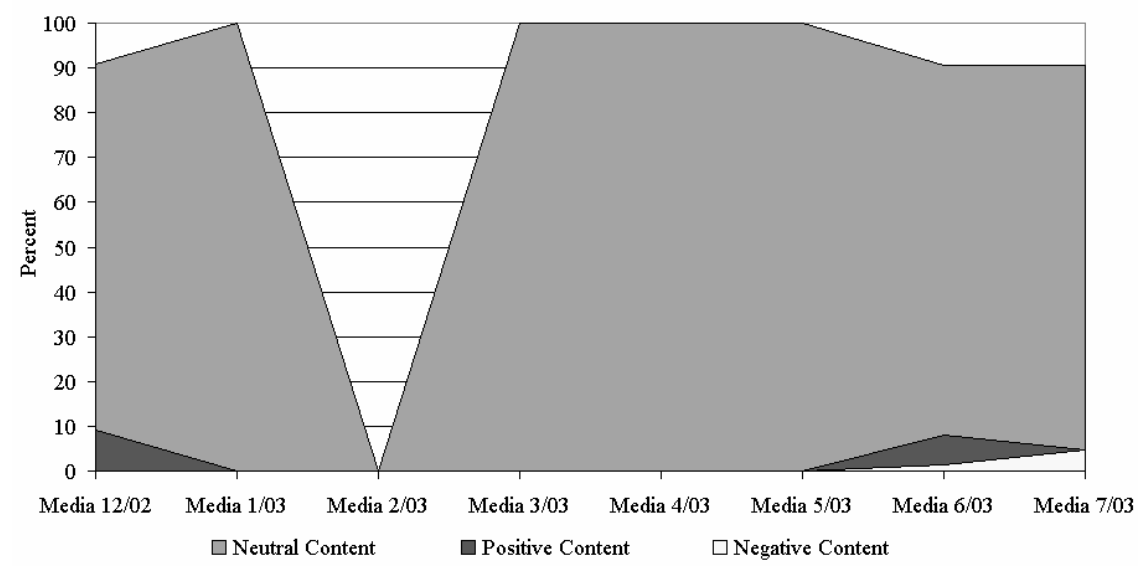

Source: Compiled by the authors. Values reflect the percentage of broadcast media segments using each tone. There were no broadcast segments in February 2003.

or even had a positive bias, but tended to become more negative over time, especially following the release of the decision in Lawrence. In addition, for both newspapers and television news programs, headlines and segment leads often had even more negative bias than the full articles and news program segments, with this bias also increasing in June and July 2003. The increase in negative coverage for both newspapers and the broadcast media coincided with the Court's handing down of its decision in the case, when media coverage of the case was most intense and more people were exposed to it (Haider-Markel, Allen, and Johansen 2006).

Although it is impossible to rule out alternative causes of the shift in public opinion following the Court's decision (Johnson and Martin 1998), a comparison of the meaningful shifts in public opinion before and after the Lawrence decision with the pattern of the media's coverage of the case suggests that the media's negative coverage of the case did play a role in influencing public opinion on gay rights issues. The increase in negative coverage coincides with the sharp decline in public support on gay rights issues, as shown in Table 2. In July 2003, when the percentage of negative articles regarding the case was at nearly 20 percent in state newspapers, 6 percent in national newspapers, and 5 percent in broadcast media news programs, there were significant downward shifts in public support on gay rights issues. It seems reasonable to infer that the public responded to the decision itself as well as the tone of the media's coverage of the Lawrence 
decision, becoming less supportive of gay rights issues as negative coverage increased.

Even though it seems apparent that the media's coverage of the Lawrence case influenced public opinion on gay rights issues, what is less clear is the duration of that influence. Almost a full year following the Lawrence decision, public support on gay rights issues had started to rebound (Moore 2004). As shown in Table 2, in May 2004, 52 percent of the public supported legalized homosexual relations. Although this is still well below the 60 percent who supported legalized homosexual relations in May 2003, it is a significant increase. Larger increases in support were found on questions less directly related to the issues in the Lawrence case-support for homosexual lifestyles and civil unions. In both areas, public support levels in May 2004 had completely rebounded to their previous levels of May 2003 (Moore 2004). These findings suggest that although the media may be able to influence public opinion in its coverage of Supreme Court cases, that influence may be short-lived. However, specific support on legal homosexual relations suffered a decline in support that had still not fully rebounded almost one year later. In sum, the impact of media coverage in the case appears to have had the most long-term impact on the specific issue of the case, and not gay civil rights issues overall.

But in large part this is what we should expect. As the media turns its attention elsewhere and less coverage is provided of the Court's decision in a case or the issue generally, the public's attention will shift and opinions are likely to begin returning to their earlier positions (Franklin and Kosaki 1989, 1995; Hoekstra 2000, 2003).

\section{Intervening Factors Shaping Media Coverage}

In addition to media bias in its coverage of the Lawrence case, the structure of the Supreme Court's opinion itself may have encouraged negative media coverage and contributed to the negative shift in public opinion. Court decisions often "sow the seeds of dissension" (Franklin and Kosaki $1995,754)$, especially when the Court itself is publicly divided in its opinion on a salient issue. Because conflict often draws media coverage, conflict within the Court, manifested through dissenting opinions, can serve to intensify societal disputes and encourage negative coverage of the decision (Davis 1994).

In Lawrence, Justice Scalia, joined by Chief Justice Rehnquist and Justice Thomas, wrote a scathing dissent from the majority opinion striking down state sodomy laws. Taking the unusual step of reading his dissent from the bench when the Court announced its decision, an act Justices seldom perform except to express vehement opposition to the majority opinion 
(Lash 2003), Justice Scalia characterized the Court's decision to overrule Bowers as a "massive disruption of the current social order"(Lawrence v. Texas 2003, 591). He also sternly warned that the majority opinion paved the way for the legalization of conduct including bigamy, adult incest, adultery, bestiality, and homosexual marriage and would lead to the breakdown of laws based on moral choices, saying that "every single one of these laws is called into question by today's decision"(Lawrence v. Texas 2003, 590). In addition, Justice Scalia accused the majority of taking sides in a culture war, characterizing the majority opinion as being the "product of a law-profession culture, that has largely signed on to the so-called homosexual agenda, by which I mean the agenda promoted by some homosexual activists directed at eliminating the moral opprobrium that has traditionally attached to homosexual conduct" (Lawrence v. Texas 2003, 602).

Justice Scalia's dramatic and critical dissent may have served to foster more negative media coverage of the decision and, therefore, may have contributed to the corresponding decline in public support for gay rights issues. Indeed, 96 percent of the national newspaper articles in our sample that were coded negative provided more than one paragraph of coverage to Justice Scalia's dissenting opinion, whereas none of the positive articles provided more than one paragraph of coverage to the dissenting opinion. In just one example a USA Today article on the case contained the following description: "In a fiery dissent that he read from the bench, Justice Antonin Scalia said the ruling will lead to government-sanctioned gay marriages: 'Today's opinion dismantles the structure of constitutional law that has permitted a distinction to be made between heterosexual and homosexual unions, insofar as formal recognition in marriage is concerned" (Biskupic 2003, 5A). In this article, as in many, the paragraph or more on Justice Scalia's remarks segued into quotes from a variety of public figures who disagreed with the Court's decision in the case.

In general, the release of highly critical dissenting opinions by Supreme Court justices could possibly encourage negative media coverage of a case and play a role in influencing relevant public opinion. Such actions may serve to make the activities of the Court and its relations with the media less of an "invisible dance," which may increase public knowledge, but might also serve to undermine trust in the Court and acceptance of the legitimacy of its decisions (Davis and Strickler 2000).

In fact, a FOX News/Opinion Dynamics Poll taken in the days immediately following the decision in Lawrence found that 44 percent of respondents disagreed with the "Supreme Court's decision overturning the Texas law that prohibited gay sex," while 40 percent approved and 16 percent were unsure. Meanwhile, Gallup polls of national adults taken in September 2002 and September 2003 found an increase of 9 percentage points in respondents 
who said that they had not very much or no "trust and confidence" in the Supreme Court. Likewise, in the same time period Gallup reported a 9 percentage-point increase in respondents disapproving of the "way the Supreme Court is handling its job." Although similar shifts in attitudes towards the Court have been documented in other controversial decisions, such as Bush v. Gore, such dramatic shifts are unusual (Kritzer 2001). Nevertheless, if the public does not have confidence in the Court, enforcing the Court's decisions becomes exceedingly difficult (Davis 1994).

\section{Concluding Thoughts}

In summary, our analysis has several key findings. First, in our examination of whether increases in public support on gay civil rights issues over time corresponded with increases in media coverage of major gay rights cases appearing before the Supreme Court since 1985, we found that there was a significant correlation - as the public became more supportive of gay rights, the news media provided more coverage of gay rights cases before the Court. This finding suggests that perhaps the media responds to changes in public opinion about policy issues and adjusts the amount of its coverage of relevant Supreme Court cases accordingly.

Second, any connection between public opinion and media coverage is significant not only because it suggests that public opinion can influence the media's coverage but also because the media is generally the public's sole source of information about Supreme Court decisions and the implications of these decisions. When the Court hands down decisions that have a significant impact on public policy, the public should have a clear understanding of the decision, the issues involved, and the policy impact of the decision.

Third, our analysis of tone in media coverage of the Supreme Court's June 2003 decision in Lawrence v. Texas and the direction of public support for gay rights revealed a significant and abrupt downward shift in public support on gay rights issues just one month following the Court's decision in Lawrence. The pattern of increasingly negative media coverage of the case by the media was associated with a dramatic shift in public opinion on gay rights issues following the Lawrence decision. Our analysis of aggregate and individual level data suggests that public opinion did change as a result of the Court's decision, and this was likely enhanced by the media's increasing negative coverage of the case. In addition, the increase in negative media coverage may have partly been a result of Justice Scalia's scathing dissent from the majority opinion, in which he outlined how the majority decision undermined moral values in America. Overall our analysis supports the notion that the combination of the Court's decision to overturn state sodomy laws, negative media coverage of the decision, and the dissent of a minority 
of justices interacted to contribute to a decline in support for gay civil rights, and may have also undermined public confidence in the Court.

Finally, consistent with previous research, our analysis suggests that any understanding of the potential relationship between the Supreme Court and public opinion should account for the filtering role of the media (Hoekstra 2003; Slotnick and Segal 1998). Unlike members of Congress, the Court does not send out constituent mail describing its latest activities, and unlike the president, Justices do not normally give public speeches explaining the reasoning behind their decisions (Davis 1994). Instead, the Court relies on the media to do those activities for it, giving the media the ability to not only direct attention to certain issues but also to shape public understanding of Court decisions and, potentially, public attitudes about policy issues.

\section{NOTES}

${ }^{1}$ For the Boy Scouts of America v. Dale searches, we used the Newark Star-Ledger rather than the Trenton Trentonian because the Newark paper was much larger and the Trenton paper could not be searched using existing databases. Here we exclude the Associated Press and USA Today to simplify our presentation. Searches of these outlets are included in the analysis below. We selected these outlets because they have the largest national circulation and website viewership.

${ }^{2}$ In addition, a Granger Causality test reveals that the directional relationship is from opinion to news coverage. The results suggest that support for legal same-sex relations granger causes news coverage (Chi Square 8.3588, p. $>0.015$ ), but news coverage does not significantly granger cause support for legal same-sex relations (Chi Square 3.2483, p. >0.197).

${ }^{3}$ This finding has been collaborated with similar analysis of Gallup poll data just prior to and following the Lawrence decision (Stoutenborough, Haider-Markel, and Allen 2006).

${ }^{4}$ Michigan could possibly have been included in this analysis because there had been ambiguity concerning the status of its sodomy law since 1992. We chose not to include Michigan because the state chose not to appeal a 1990 court ruling that overturned the state's sodomy law.

${ }^{5}$ Two researchers conducted the coding of the articles and the inter-coding match or reliability was nearly $92 \%$. On the few items were there was disagreement, the articles were simply coded as neutral. For examples of articles and coding see http://people.ku.edu/ dhmarkel/data.html.

${ }^{6}$ The state capital city newspapers included in our study are: Jefferson City News (MO), The Daily Oklahoman (OK), The State (SC), The Advocate (LA), Austin-American Statesman (TX), Topeka Capital Journal (KS), The Salt Lake Tribune (UT), The News and Observer (NC), The Idaho Statesman (ID), Tallahassee Democrat (FL), Richmond Times Dispatch (VA), Clarion-Ledger (MS), and Montgomery Advertiser (AL). 


\section{REFERENCES}

Baumgartner, Frank. R., and Bryan D. Jones. 1993. Agendas and Instability in American Politics. Chicago: University of Chicago Press.

Behr, Roy L., and Shanto Iyengar. 1985. Television News, Real-World Cues, and Changes in the Public Agenda. Public Opinion Quarterly 49:38-57.

Biskupic, Thomas. 2003. Decision Represents an Enormous Turn in the Law. USA Today, June 27, p. 5A.

Brewer, Paul R. 2003. The Shifting Foundations of Public Opinion about Gay Rights. Journal of Politics 65:1208-1220.

Caldeira, Gregory A. 1987. Public Opinion and the U.S. Supreme Court: FDR's CourtPacking Plan. American Political Science Review 81:1139-1153.

Clawson, Rosalee A., Elizabeth R. Kegler, and Eric N. Waltenburg. 2001. The Legitimacy-Conferring Authority of the U.S. Supreme Court: An Experimental Design. American Politics Research 29:566-591.

Clawson, Rosalee A., and Eric N. Waltenburg. 2003. Support for a Supreme Court Affirmative Action Decision: A Story in Black and White. American Politics Research 31:251-279.

Clawson, Rosalee A., H.C. Strine IV, and Eric. N. Waltenburg. 2003. Framing Supreme Court Decisions: The Mainstream versus the Black Press. Journal of Black Studies 33:784-800.

Craig, Stephen C., Michael D. Martinez, James G. Kane, and Jason Gainous. 2005. Core Values, Value Conflict, and Citizens' Ambivalence about Gay Rights. Political Research Quarterly 58:5-17.

Davis, Richard. 1994. Decisions and Images: The Supreme Court and the Press. Englewood Cliffs, NJ: Prentice Hall.

Davis, Richard, and Vincent James Strickler. 2000. The Invisible Dance: The Supreme Court and the Press. Perspectives on Political Science 29:85-92.

Egan, Patrick J., and Kenneth Sherrill. 2005. Neither an In-Law nor an Outlaw Be: Trends in Americans' Attitudes Toward Gay People. Public Opinion Pros (February), online http://www.publicopinionpros.com/.

Epstein, Lee, and Jeffrey Segal. 2000. Measuring Issue Salience. American Journal of Political Science 44:66-83.

Franklin, Charles H., and Liane C. Kosaki. 1989. Republican Schoolmaster: The U.S. Supreme Court, Public Opinion, and Abortion. American Political Science Review 83:751-771.

Franklin, Charles H., and Liane C. Kosaki. 1995. Media Knowledge and Public Evaluations of the Supreme Court. Pp. 352-375 in Contemplating Courts, ed. Lee Epstein. Washington, DC: Congressional Quarterly Press.

Haider-Markel, Donald P. 2002. Lesbian and Gay Politics in the States: Interest Groups, Electoral Politics, and Public Policy. Pp. 290-346 in The Politics of Gay Rights, eds. Rimmerman et al. New York: Chatham House.

Haider-Markel, Donald P., and Mark R. Joslyn. 2005. Attributions and the Regulation of Marriage: Considering the Parallels Between Race and Homosexuality. P.S.: Political Science \& Politics. 38:233-239.

Haider-Markel, Donald P., Mahalley D. Allen, and Morgen Johansen. 2006. Understanding Variations in Media Coverage of U.S. Supreme Court Decisions: Comparing Media Outlets in their Coverage of Lawrence v. Texas. Harvard International Journal of Press/Politics 11:64-85. 
Hoekstra, Valerie. 2000. The Supreme Court and Local Public Opinion. American Political Science Review 94:89-108.

Hoekstra, Valerie. 2003. Public Reaction to Supreme Court Decisions. Cambridge: Cambridge University Press.

Iyengar, Shanto. 1991. Is Anyone Responsible? How Television Frames Political Issues. Chicago: University of Chicago Press.

Iyengar, Shanto, and Donald R. Kinder. 1987. News That Matters. Chicago: University of Chicago Press.

Jeon, Yongjoo, and Donald P. Haider-Markel. 2001. Tracing Issue Definition and Policy Change: An Analysis of Disability Issue Images and Policy Response. Policy Studies Journal 29:215-231.

Johnson, Timothy R. and Andrew D. Martin. 1998. The Public's Conditional Response to Supreme Court Decisions. American Political Science Review 92:299-309.

Joslyn, Mark R., and Donald P. Haider-Markel. 2000. Guns in the Ballot Box: Information, Groups, and Opinion in Ballot Initiative Campaigns. American Politics Quarterly 28:355-378.

Kritzer, Herbert M. 2001. The Impact of Bush v. Gore on Public Perceptions and Knowledge of the Supreme Court. Judicature 85:32-38.

Lash, Steve. 2003. Contentious, Emotional Supreme Court Session. Austin-American Statesman, June 29, p. H4.

Lewis, Gregory, and Rogers, Marc. 1999. Does the Public Support Equal Employment Rights for Gays and Lesbians? Pp. 118-145 in Gays and Lesbians in the Democratic Process, eds. Ellen D. B. Riggle and Barry L. Tadlock. New York: Columbia University Press.

Menashe, Claudia L., and Siegel Michael. 1998. The power of a frame: an analysis of newspaper coverage of tobacco issues-United States, 1985-1996. Journal of Health Communication 3:307-325.

Moore, Jennifer. 2004. Modest Rebound in Public Acceptance of Homosexuals. The Gallup Organization. Retrieved May 20, 2004, from http://www.gallup.com.

Nelson Thomas E., Rosalee A. Clawson, and Zoe M. Oxley. 1997. Media Framing of a Civil Liberties Conflict and its Effect on Tolerance. American Political Science Review 91:567-583.

Nelson, Thomas E., and Zoe M. Oxley. 1999. Issue Framing Effects on Belief Importance and Opinion. Journal of Politics 61:1040-1067.

Newport, Frank. 2003. Public Shifts to More Conservative Stance on Gay Rights. The Gallup Organization. Retrieved July 30, 2003, from http://www.gallup.com.

Scherer, Nancy. 2003. The Judicial Confirmation Process: Mobilizing Elites, Mobilizing Masses. Judicature 86:240-250.

Shah, Dhavan V., Mark D. Watts, David Domke, David P. Fan, and Michael Fibison. 1999. News Coverage, Economic Cues, and the Public's Presidential Preferences: 1948-1996. Journal of Politics 61:914-943.

Slotnick, Elliot E., and Jennifer A. Segal. 1998. Television News and the Supreme Court: All the News That's Fit to Air? Cambridge: Cambridge University Press.

Stoutenborough, James W., Donald P. Haider-Markel, and Mahalley D. Allen. 2006. Reassessing the Impact of Supreme Court Decisions on Public Opinion: Gay Civil Rights Cases. Political Research Quarterly 59:419-433.

Wlezien, Christopher B., and Malcolm L. Goggin. 1993. The Courts, Interest Groups, and Public Opinion about Abortion. Political Behavior 15:381-405.

Wood, Peter B., and John P. Bartkowski. 2004. Attribution Style and Public Policy Attitudes Toward Gay Rights. Social Science Quarterly 85:58-74. 
230 | Mahalley D. Allen and Donald P. Haider-Markel

\section{Cases Cited}

Bowers v. Hardwick. 1986. 478 U.S. 186.

Boy Scouts of America v. Dale. 2000. 530 U.S. 640.

Lawrence v. Texas. 2003. 539 U.S. 558.

Romer v. Evans. 1996. 517 U.S. 620. 